\title{
The effect of e-learning in developing high thinking skills
}

\section{Ni'mat Rababa ${ }^{a^{*}}$}

\author{
Article history: \\ Received: September 9, 2020 \\ Received in revised format: Sep- \\ tember 9, 2020 \\ Accepted: November 6, 2020 \\ Available online: November 6, \\ 2020 \\ Keywords: \\ E-learning \\ High thinking skills \\ Educational Objectives
}

${ }^{a}$ Educational Counseling, Jordan University, Jordan

\begin{abstract}
A B S T R A C T
This research aims to investigate the impact of adopting e-learning in an attempt to enhance higher thinking skills among students at the University of Jordan. In addition, we examine the relationship between e-learning and higher thinking skills and identify the effect of e-learning on higher thinking skills at the University of Jordan. The study examines the effect of using e-learning effectiveness and its effect on developing higher students' thinking skills at the university level. The study also focuses on intellectual education for high-level thinking and the impact of the e-learning environment on a group of students at the University of Jordan. The target community for this study is undergraduate students at the University of Jordan, in Amman, Jordan. The resulted sample consists of 45 students. During the experiment, two research tools were used to analyze the relationship between the independent and dependent variables. The quantitative data are collected from the students' perception analyzed using some statistical tests. The results of the research indicate that students could be helped to enhance higher-order thinking skills and maybe enriched by integrating an e-learning model into teaching and learning. There is also a positive relationship between e-learning and higher thinking skills at the University of Jordan. The experimental results of this study indicate several results, as the adoption of the e-learning model led to a significant improvement in the higher thinking skills of students. The e-learning model can remove many social and cultural barriers.
\end{abstract}

\section{Introduction}

Information technology has affected all aspects of our lives. The Internet, as one of the most influential technologies of the twentieth century, has changed the way of doing business (e-commerce), the way people communicate (e-mail), and the way people train / learn (e-training), and also the way people learn (e-learning). E-learning is an innovative development in all educational institutions (Foray, 2004). Higher education institutions in particular are interested in adopting this innovation to break the constraints of time and place of classroom lectures (Guri-Rosenblit, 2005). Due to the flexibility and accessibility of e-learning, it is considered by many to use revolutionary methods of teaching and learning (Tzouveli et al., 2004). The social and governmental requirements of higher education are the main factors that continue to shape the goals and strategies of universities, as these demands continue to pressure universities to ensure that more students receive higher education (Laurillard, 2005). E-learning is however a successful method of teaching (Zemsky \& Massy, 2004). Higher-order thinking skills have been described as a high-level thinking activity that requires a set of cognitive skills (Burden \& Byrd, 1994). In addition, many recent studies indicate that students' critical thinking skills can be enhanced through the e-learning model (Dinevski et al., 2003), where encouraging students to develop critical thinking skills has become an important issue in higher education (Grafstein, 2007). In the early twentieth century, the primary purpose of education was to learn to think, as the emphasize on education was to address the teachers on thinking rather than focusing on just teaching the subject only. Educators constantly stress the importance of developing thinking skills that can be practiced in life experiences. Educators widely believe that developing the ability to think should be the primary goal of education (Pithers \& Soden, 2000). The Internet has created new 
paradigms of learning that allow teachers and students to teach and learn collaboratively through web-designed courses (Dowling, 2003). The changing nature of technology has not only provided us with more and better ways to teach, but it has also increased the need for higher-order thinking skills. The above studies provide valuable information, which indicate that students' higher-order thinking skills can be strengthened through an e-learning environment. To ensure the effectiveness of the e-learning environment in developing higher students' thinking skills, this research tries to explore the influencing relationships between the effectiveness of e-learning in developing higher thinking skills among students at the University of Jordan, as it seeks to find out whether different measurements and treatments lead to various results.

\subsection{Research Importance}

This research is very important nowadays, mainly because e-learning is a new paradigm for education and training (Mikic \& Anido, 2006). Not only did it ask serious questions from academics, but it also fostered a wealth of new prospects for the future of education (Oneill, 2004). Research that uses quantitative methods to research the effect of e-learning on higher education skills is more than research that uses qualitative methods, as some research has combined both methods (Bates \& Bates, 2005). Consequently, this research focuses attention on the qualitative impact of e-learning, which is an area that needs great attention and a lot of studies. As a result, this research provides additional knowledge of the field of technology-enhanced learning environments, which may benefit university decision-makers, academic advisors, faculty, and students. Empirical data collected on students' perceptions of satisfaction in an e-learning environment can be used to determine the benefits and limitations required to make informed decisions regarding the e-learning program and development strategies. What makes this research particularly unique is that it was conducted within the context of Arab culture. Whereas, no research of this kind was conducted in Jordan or Jordanian universities. One of the intended results of this research is that the results can be used to suggest new ways to promote critical thinking for students in higher education institutions across Jordan and the Arab world. The results can help teachers improve education and provide them with recommended activities that can be used to motivate students to active learning. Moreover, e-learning policymakers can use the results of this research to shape and develop educational strategies, procedures, and policies that enhance e-learning in their educational institution. In this way, we can meet the changing educational requirements of the twenty-first century.

\subsection{Research Aims}

The aim of this research is to investigate the effect of adopting e-learning in an attempt to enhance higher thinking skills among students at the university level of the University of Jordan. Therefore, the research objectives are as follows:

- Examining the relationship between e-learning and higher-order thinking skills,

- Learning about the impact of e-learning on higher-order thinking skills at the University of Jordan.

\section{Research Questions and Hypotheses}

$\mathrm{H}_{1}$ : Is there a statistically significant relationship between the effect of e-learning and high thinking skills on the educational level at significance level $=0.05$ ?

$\mathrm{H}_{2}$ : Are there statistically significant differences between the mean of the two categories of e-learning and traditional learning at significance level $=0.05$ ?

\section{Research Methodology}

The analytical approach will be used in this research to suit its requirements and achieve its objectives. A questionnaire has been developed to evaluate the effectiveness of e-learning, which explores students' attitudes towards the new learning environment. Whereas, the questionnaire is a data collection tool that identifies the factors that affect students' attitudes towards e-learning, as it is experimental.

\subsection{Research community}

The research community is defined as the entire research population (Douwery, 2000). The research community consists of the University of Jordan students, and the study sample size was determined to be 45 students in the e-learning groups and 45 in the traditional groups.

\subsection{Data collection tool:}

Research data was collected using the questionnaire as a tool to collect data related to this research, as the questionnaire is one of the most used scientific research tools. The questionnaire seeks to know the extent of students' satisfaction with the elearning model in teaching. Student satisfaction can be defined as the students' perception regarding the overall experience and perceived value of education. In other words, this questionnaire attempts to determine students' attitudes towards e-learning. Identifying such situations will determine critical success factors in e-learning. Demographic information was obtained from the students' questionnaire as this information supports the researcher's decision to conduct analyzes based on gender differences. Concerning breakdowns by gender, the number of participants consisted of 23 males and 22 females. The second 
part consists of questions that test students 'familiarity with computer technology. Hypothetically, a student with strong computer knowledge has a positive tendency towards e-learning since there are few or no problems with the technical expertise level. The third section includes questions that explore students' attitudes towards e-learning. These situations illustrate how cultural background affects students' perception of e-learning. Every statement in the survey was based on Likert scale answers, and each answer to determine scores normally distributed based on the pooled responses. For the research questions, including the Likert scale that answers the research questions, two different statistical methods of analysis were used. The descriptive statistics method was used to obtain the ratios of means and responses to compare these values with each other and compare them with the specified Likert scale questions. The second method was the inferential methods, which added validity to the descriptive statistical results as the ANOVA and CHAI tests were used.

\subsection{Sample Characteristic}

The properties of the search sample are shown as shown in Fig. 1:

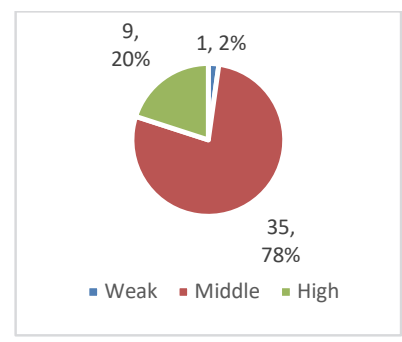

English Language

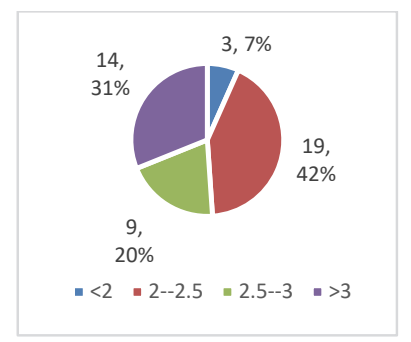

GPA

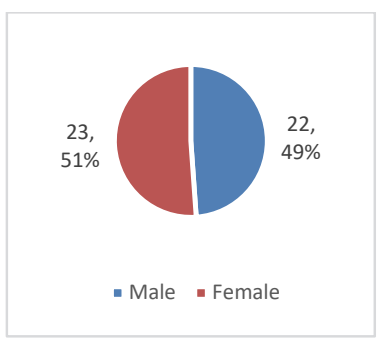

Gender

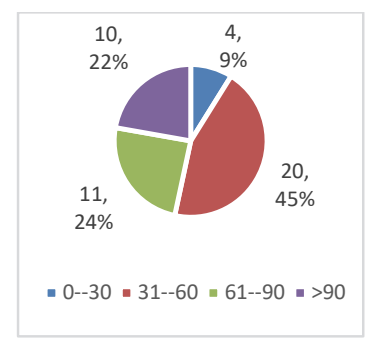

Passed Hours

Fig. 1. Demographic information of the participants

\subsection{Variables}

Independent variable: E-Learning

Dependent variable: High thinking skills

\section{Results}

The questionnaire consists of 37 questions and is divided into two parts. The first section is the collection of the respondents' personal data. The second part of the survey measures participants' e-learning behaviors. Fig. 1 displays the findings from demographic information and descriptive statistics of the respondents from the initial portion of the survey.

\subsection{Pre-test:}

The pre-test was done as shown in Table 1 on the two categories to ensure compatibility between them before the post-test

Table 2

Table 1

Pre-test

\begin{tabular}{lccccc}
\hline Category & Sam- & Mean & SD & T & Signifi- \\
\hline E-learning & 45 & 6.67 & 2.66 & 0.16 & 0.945 \\
Traditional & 45 & 6.10 & 3.14 & & \\
\hline
\end{tabular}

T-test results for the two categories of e-learning and traditional learning

\begin{tabular}{|c|c|c|c|c|c|}
\hline \multirow{2}{*}{$\begin{array}{c}\text { Higher } \\
\text { thinking } \\
\text { skills }\end{array}$} & \multicolumn{2}{|c|}{$\begin{array}{c}\text { Traditional } \\
\text { learning sample }\end{array}$} & \multicolumn{2}{|c|}{$\begin{array}{c}\text { E-learning } \\
\text { sample }\end{array}$} & \\
\hline & $\mathrm{SD}$ & Mean & $\mathrm{SD}$ & Mean & \\
\hline Evaluation & 1.7 & 6.6 & 1.47 & 4.45 & 4.55 \\
\hline Analysis & 1.85 & 7.9 & 1.7 & 4.3 & 5.00 \\
\hline Application & 1.68 & 6.9 & 1.51 & 3.66 & 5.12 \\
\hline Knowledge & 1.64 & 5.0 & 1.44 & 3.58 & 5.56 \\
\hline Total & 1.71 & 6.6 & 1.53 & 3.99 & \\
\hline
\end{tabular}

To examine the validity of the hypotheses, the researcher worked on a comparison between the two categories by analyzing the variance at a statistical significance of 0.05 according to Table 2 . Based on the Table 2, it is evident that the students' sample category in e-learning was superior to the students of the other category concerning the assessment. The arithmetic mean was 6.6, while the traditional learning category averaged 4.45, and t-value reached 4.55, which is higher than the tabular value 2.02 . The category of the students' sample in e-learning surpassed the students of the other category with the analysis, as the arithmetic mean was 7.9, while the traditional learning category averaged 4.3, with t-value of 5, which is higher than the tabular value 2.02. As for the group of students in e-learning, it surpassed the students of the other category in terms of application, the arithmetic mean was 6.9 , and the traditional learning group averaged 3.66, with the t-value of 5.12, which is higher than the tabular value 2.02. As for knowledge, the value of the arithmetic mean of 5 in electronic learning surpassed the traditional value, which amounted to 3.58, and the value of t-value reached 5.56, which is higher than the tabular value. Table 3 shows the E-learners and the reasoning skills of everyone who learned via the traditionally used method among groups in the test of unilateral variance are the variation among the level of high thinking skills, which is statistically important at (0.05) levels. 
Table 3

Analysis of variance

\begin{tabular}{lccccc}
\hline Higher thinking skills & $\mathrm{F}$ & $\mathrm{df}$ & Mean Square & Variance & Eta Square \\
\hline Evaluation & 13.51 & 1 & 8.6 & Between Groups & 0.15 \\
Analysis & 12.65 & 1 & 7.9 & & 0.13 \\
Application & 14.48 & 1 & 9.7 & & 0.14 \\
Knowledge & 15.76 & 1 & & & 0.16 \\
\cline { 1 - 4 } Total & & & 9.175 & & 0.15 \\
Evaluation & & 60 & 41.2 & & \\
Analysis & & 60 & 46.0 & & \\
Application & 60 & 48.1 & & \\
Knowledge & & 60 & 51.6 & & \\
\hline Total & & 46.71 & & \\
\hline
\end{tabular}

When we analyze the value of $F$, it is evident that its values reached 13.51 with an importance of 0.05 for the assessment and 12.65 in the meaning of 0,05 for the study. With regards to the implementation, it reached 0.05 at 14.48 and reached 15.76 with information. When analyzing the partial ATA box, e-learning 's influence on higher thinking competencies is calculated, as the values exceed 0.15 in the test, and the study reached an average value of 0.13 . The mean value for the application was 0.14 , and the value of information was 0,16 .

\section{Conclusion}

E-learning plays a pivotal role in the transformation of higher education. It can promote educational reform by creating a paradigm shift from teacher-centered and memory-based education to student-centered education where students work collaboratively, build their knowledge, and foster critical thinking. The results of this research indicate that e-learning can create effective education and provide students with good quality education. Technology assistance can be effective in serving educational goals with a careful instructional design. E-learning can lead to a paradigm shift in education, but this requires designing new curricula in teaching that integrate technology into the learning process to serve educational goals. The results from the research indicated that it could help students learn critical thinking that might be enriched by integrating the elearning model in teaching and learning. In conclusion, and based on the data presented in this research, the researchers have concluded that adopting the e-learning model may be effective in enhancing students' thinking skills. The researchers propose to the university administration to pursue e-learning more broadly because of its impact on higher-order thinking skills in achieving educational goals and strengthening the structure for e-learning. The researcher also suggests that other studies be conducted in the future, and more broadly to include larger segments.

\section{Acknowledgement}

In this research, the author would also like to bless her parents and family for their continuing support. In addition, no specific grants from publicly funded sources.

\section{References}

Douwery, R. (2000). Scientific research, its theoretical foundations, and scientific practices. Lebanon: The House of Contemporary Thought. Bates, A. W., \& Bates, T. (2005). Technology, e-learning and distance education. Psychology Press.

Burden, P. R., \& Byrd. D.M. (1994). Methods for effective teaching.

Dinevski, D., Ojsteršek, M., \& Plenković, M. (2003, January). Information technology platform for e-learning implementation. In 10. Međunarodni znanstveni skup Društvo i tehnologija.

Dowling, C. (2003). New educational technologies: do they improve learning? On the Horizon.

Foray, D. (2004). Economics of knowledge. MIT press.

Grafstein, A. (2007). Information literacy and technology: An examination of some issues. portal: Libraries and the Academy, 7(1), 51-64.

Guri-Rosenblit, S. (2005). 'Distance education'and 'e-learning': Not the same thing. Higher education, 49(4), 467-493.

Laurillard, D. (2005). Harnessing technology: Transforming learning and children's services.

Mikic, F., \& Anido, L. (2006, April). Towards a Standard for Mobile E-Learning. In International Conference on Networking, International Conference on Systems and International Conference on Mobile Communications and Learning Technologies (pp. 217-217). IEEE.

Oneill, K., Singh, G., \& O'donoghue, J. (2004). Implementing eLearning programmes for higher education: A review of the literature. Journal of Information Technology Education: Research, 3(1), 313-323.

Pithers, R. T., \& Soden, R. (2000). Critical thinking in education: A review. Educational research, 42(3), 237-249.

Tzouveli, P., Mylonas, P., \& Kollias, S. (2008). An intelligent e-learning system based on learner profiling and learning resources adaptation. Computers \& Education, 51(1), 224-238.

Zemsky, R., \& Massy, W. (2004). Thwarted innovation: What happened to e-learning and why. Philadelphia, PA: The Learning Alliance at the University of Pennsylvania.

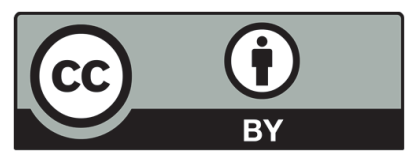

(C) 2021 by the authors; licensee Growing Science, Canada. This is an open access article distributed under the terms and conditions of the Creative Commons Attribution (CC-BY) license (http://creativecommons.org/licenses/by/4.0/). 